\title{
Congenital contractural arachnodactyly
}

INSERM

\section{Source}

INSERM. (1999). Orphanet: an online rare disease and orphan drug data base. Congenital contractural arachnodactyly. ORPHA:115

Cong enital contractural arachnodactyly (CCA, Beals syndrome) is a connective tissue disorder characterized by multiple flexion contractures, arachnodactyly, severe kyphoscoliosis, abnormal pinnae and muscular hypoplasia. 